\title{
Higher Tolerance to Abiotic Stresses and Soil Types May Accelerate Common Ragweed (Ambrosia artemisiifolia) Invasion
}

\author{
Huseyin Onen, Shahid Farooq, Hikmet Gunal, Cumali Ozaslan, and Halil Erdem*
}

\begin{abstract}
Common ragweed is a troublesome allergenic invader and noxious weed of several crops. Despite extensive research to understand the factors affecting its invasion, the role of environmental stresses and soil types on survival and growth is poorly understood. The objective of this study was to determine the effects of drought, salinity, and soil types on survival, growth, and nutrient uptake of ragweed in greenhouse experiments to predict its invasiveness in Turkey. Three separate experiments, with five drought intensities $(100,75,50,25$, and $12.5 \%$ of field capacity [FC]), four levels of salinity $(0,3,6$,

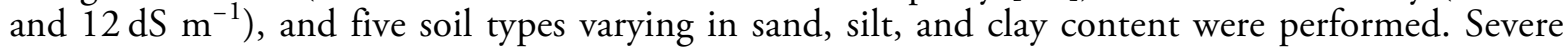
drought and salinity levels reduced seedling survival, while soil type had no effect. Increasing drought and salinity negatively affected growth and nutrient uptake; the poorest growth was observed under severe drought intensity. Ragweed exhibited intensive tolerance to drought, even severe levels, while it tolerated salinity up to $6 \mathrm{dS} \mathrm{m}$ for seedling survival. Growth was negatively affected above $3 \mathrm{dS} \mathrm{m}^{-1}$. The highest and lowest nutrient accumulations were recorded under moderate and extreme drought intensities, respectively. Similarly, the highest $\mathrm{Na}$ accumulation was observed under extreme saline conditions, whereas the highest $\mathrm{P}$ uptake and $\mathrm{K} / \mathrm{Na}$ ratio were achieved under nonsaline conditions $\left(0 \mathrm{dS} \mathrm{m} \mathrm{m}^{-1}\right)$. Variation of soil texture had no effect on growth and nutrient uptake. The highest $\mathrm{Ca}, \mathrm{Mg}$, and $\mathrm{Na}$ accumulations were recorded on clay soil, while higher $\mathrm{P}$ accrued on sandyloam soil. Increased tolerance of ragweed to severe drought and moderate salinity and its nonselective nature for soil type indicate that semiarid and partially arid regions in Turkey have plenty of vacant niches for ragweed invasion.
\end{abstract}

Nomenclature: Ragweed, Ambrosia artemisiifolia L. AMBEL

Key words: Abiotic stress, distribution, phenotypic plasticity, semiarid region, soil texture

Biological invasions have attracted increased attention from scientists, public organizations, and politicians because of their negative impacts on native biodiversity, agriculture, human health, and regional economies (Chown et al. 2015; Vila et al. 2011; Ziska et al. 2011). Invasive plants are recognized as major threats to biodiversity and ecosystem services among all invaders, and have been studied in the last decades (Hulme et al. 2013). Although artificial disturbance of habitat is the main driver of biological invasions, global climate change (Chown et al. 2015) and increased global trade of agricultural products are also expected to accelerate plant invasion.

Plant distribution is mainly regulated by environmental factors (e.g., physicochemical properties of soils, presence of microorganisms, water and gas

\footnotetext{
DOI: 10.1614 /WS-D-16-00011.1

* First and second authors: Professor and Graduate Student, Department of Plant Protection, Gaziosmanpaşa University, Tokat 60240, Turkey; third and fifth authors: Professor and Associate Professor, Department of Soil Science and Plant Nutrition, Gaziosmanpaşa University, Tokat 60240, Turkey; fourth author: Assistant Professor, Department of Plant Protection, Dicle University, Diyarbakir 21280, Turkey. Corresponding author's E-mail: csfa2006@gmail.com
}

content), climatic conditions (temperature, precipitation, and light availability) and interactions among plant species (Klironomos 2002). Soil salinity and water scarcity play a significant role in shaping plant communities, disturbing nutritional balances, water uptake, and photosynthesis and respiration and increasing ion toxicity (Brauer and Geber 2002; Cuin et al. 2003; Davenport and Tester 2000; Rothfels et al. 2002). However, invasive plants have unique abilities to rapidly acclimatize and invade new environments by expressing superior traits such as higher biomass production, better growth rate and nutrient uptake, shorter life span, and phenotypic plasticity (Pysek and Richardson 2007) compared with native plants. These unique adaptive abilities facilitate invasion of nonnative plants to new habitats with diverse ecosystems, soil types, and climates (Davidson et al. 2011; Hellmann et al. 2008; Laube et al. 2015). Continuous changes in climate increase the incidence of environmental stresses that affect plant growth and distribution (Chown et al. 2015). However, the knowledge of growth and developmental response of invasive plants to environmental stresses is insufficient to predict their future range expansions in arid and semiarid climates. 
Environmental tolerance of invasive plants is persistently used in predicting their potential distribution ranges at regional and global scales (Araujo et al. 2011; Petitpierre et al. 2012; Svenning et al. 2011; Wiens et al. 2010). A species-distribution modeling approach assumes that specific climatic conditions desired by particular species are present in their potential distribution ranges. Therefore, knowledge of plant responses to environmental stresses is crucial in the field of invasion biology. Although invasion trends under different resource availabilities have been well interpreted (Davis et al. 2000; Moles et al. 2012), survival, growth, and reproductive output under different abiotic stresses and soil types are often ignored when modeling potential distribution ranges of invasive plants (Araujo et al. 2011; Soberon 2007), which can lead to confusing results. Therefore, understanding the growth, development, and fecundity response of invasive plants to abiotic stresses and soil types and integrating the results while modeling their potential distribution ranges will significantly improve the reliability of results.

Common ragweed, hereafter referred to as ragweed, a member of the Asteraceae, is an invasive, windpollinated, herbaceous annual species continuously expanding its invasion range in temperate climates of the world following its first introduction from North America (Chrenova et al. 2009; Kasprzyk et al. 2011; Makra et al. 2005). Ragweed is not only the most allergenic plant but also a noxious weed in several cropping systems (Fumanal et al. 2008; Ngom and Gosselin 2014; Onen et al. 2015; Ozaslan et al. 2016; Zemmer et al. 2012).

Ragweed invasion in Turkey is more recent than in the rest of Europe, and was first reported in Turkey in 1998 (Byfield and Baytop 1998). Studies have shown that the plant has already extended its range to most parts of the country (Onen et al. 2014, 2015; Ozaslan et al. 2016), and possible risks of ragweed invasion have also been reported (Onen et al. 2015; Zemmer et al. 2012). Turkey is a biodiversity hotspot of Europe with extreme topographic and climatic diversity and hosts some 12,000 plant species (Arslan et al. 2015). In contrast to the temperate climate of Europe, a large portion of Turkey lies in arid and semiarid regions that experience cyclic droughts. Therefore, ragweed invasion and range expansion in arid and semiarid regions will not solely depend on temperature as indicated by Chapman et al. (2014) and Storkey et al. (2014) for temperate regions. Thus, growth and nutrient uptake response of ragweed to abiotic stresses and soil type needs to be explored for predicting its future invasion trend in semiarid regions of Turkey.
Environmental stresses and soil type are initial barriers restricting the establishment of exotic species into new habitats. The objective of this study was to evaluate survival, growth, and nutrient uptake of ragweed under different abiotic stresses and in different soil types. The ultimate goal of this study is to identify potential areas in arid and semiarid regions where ragweed would invade and develop management strategies.

\section{Materials and Methods}

Plant Material, Dormancy Breaking, and Germination. Ragweed seeds (from more than 40 plants) were collected in 2013 from a highly infested site $\left(41.22^{\circ} \mathrm{N}, 36.43^{\circ} \mathrm{E}\right)$ of Samsun Province. Seeds were separated from plants, cleaned, kept in glass jars, and stored at $25 \mathrm{C}$. Ragweed seeds, being highly dormant, require exposure to cold temperature before germination (Essl et al. 2015). Therefore, dormancy was broken by stratifying the seeds at $4 \mathrm{C}$ for 2 wk (Willemsen 1975). Stratified seeds were then shifted to incubators at $25 \mathrm{C}$. The germinating seedlings were transplanted into 72 -celled germination trays filled with potting mix.

Experimental Setup. Three different greenhouse experiments were conducted at Gaziosmanpaşa University, Tokat, Turkey $\left(40.33^{\circ} \mathrm{N}, 36.47^{\circ} \mathrm{E}, 640 \mathrm{~m}\right.$ above sea level). Experiments were initiated and harvested on March 3 and June 1, 2014, respectively, during the first experimental run, and on June 20 and September 18, 2014, respectively, in the second experimental run. The greenhouse was maintained at 33/22 (SD 5) C day/night temperature. Supplemental light was provided with lamps to ensure a $16 \mathrm{~h}$ photoperiod. Experiments were laid out in a completely randomized design with five replications and repeated over time (two experimental runs for each experiment). Uniformly sized, round, free-draining plastic pots $(8.8 \mathrm{~L})$ were used and filled with $2.7 \mathrm{~kg}$ of finely ground soil. Physicochemical properties of the soils used in drought, salinity, and soil texture experiments are given in Table 1 . The potting soil was supplied with $200 \mathrm{mg} \mathrm{kg}^{-1} \mathrm{~N}, 100 \mathrm{mg} \mathrm{kg}^{-1} \mathrm{P}, 125 \mathrm{mg} \mathrm{kg}^{-1} \mathrm{~K}$, $2.5 \mathrm{mg} \mathrm{kg}^{-1} \mathrm{Zn}$, and $2.5 \mathrm{mg} \mathrm{kg}^{-1}$ Fe. Initially, three seedlings of uniform height $(8 \mathrm{~cm})$ were transplanted to each pot and reduced to one per pot $10 \mathrm{~d}$ after transplanting (DAT) in all experiments. Drought and salinity treatments were initiated at this stage.

Drought Stress. Growth, seedling survival, nutrient uptake, and flowering output were observed under five 
Table 1. Physicochemical properties of the soils used in drought stress, salinity stress, and soil texture experiments.

\begin{tabular}{lcccccrrr}
\hline $\mathrm{pH}$ & $\mathrm{EC}^{\mathrm{a}}$ & $\mathrm{CaCO}_{3}$ & Clay & Sand & Silt & Organic matter & Texture class \\
\hline & $\mathrm{dS} \mathrm{m}{ }^{-1}$ & $\%$ & $\%$ & $\%$ & $\%$ & $\%$ & $\mathrm{mg} \mathrm{kg}^{-1}$ \\
$8.05^{\mathrm{b}}$ & 0.31 & 14.6 & 67.7 & 12.3 & 20.0 & 1.15 & Clay & Clay \\
$7.58^{\mathrm{b}}$ & 0.85 & 8.1 & 50.2 & 14.8 & 35.0 & 2.58 & Clay & 47.31 \\
$8.38^{\mathrm{c}}$ & 0.33 & 13.5 & 48.2 & 35.0 & 16.8 & 1.47 & 7.49 \\
$7.76^{\mathrm{b}}$ & 0.17 & 7.5 & 32.7 & 19.8 & 47.5 & 1.54 & Silty-clay loam \\
$7.54^{\mathrm{b}}$ & 0.28 & 5.8 & 32.7 & 47.3 & 20.0 & 4.17 & Sandy loam \\
\hline
\end{tabular}

a Abbreviation: EC, electrical conductivity.

${ }^{\mathrm{b}}$ Soil used in soil texture experiment.

${ }^{\mathrm{c}}$ Soil used in drought and salinity stress experiments.

different pot water contents; $100 \%$ (well watered), $75 \%$ (mild drought), 50\% (moderate drought), 25\% (severe drought), and $12.5 \%$ (extreme drought) of FC. Drought treatments were set up according to methods described in earlier studies (Chauhan 2013; Chauhan and Johnson 2010; Webster and Grey 2008). The FC of soil was determined at the start of the experiments. Briefly, pots were irrigated until water started to drip from the bottoms. Irrigation was stopped at this point, and pots were covered individually with polyethylene sheets to minimize evaporation. Pots were allowed to freely drain extra water for $24 \mathrm{~h}$. The pots were reweighed to determine the FC, as described by Steadman et al. (2004). Each pot was weighed daily to determine the amount of transpired water and irrigated accordingly to maintain the desired FC. During later growth stages, pots were weighed and irrigated twice a day at 900 and 1900 hours due to increased evapotranspiration.

Salinity Stress. Salinity sensitivity of ragweed was studied to determine the effects of salinity on growth, seedling survival, and nutrient uptake. The tested salinity levels were; 0 (control), 3 (moderate salinity), 6 (severe salinity), and $12 \mathrm{dS} \mathrm{m}^{-1}$ (extreme salinity). Salinity was imposed by applying $\mathrm{NaCl}$ solution of known concentration to the pots (Ünlükara et al. 2008). Salinity was slowly increased in the pots $\left(3 \mathrm{dS} \mathrm{m}^{-1}\right.$ per application) until the desired concentration was achieved. Salinity treatments were completely imposed in $1 \mathrm{wk}$.

Soil Texture. Particle size distribution (texture) determines the ability of soil to hold nutrients and water. Therefore, growth, seedling survival, and nutrient uptake (to infer the soil type preference of ragweed) were observed using five soils with varying textures (clay-1 $[67.7 \%$ clay $]$, clay-2 $[50.2 \%$ clay $+35 \%$ silt $]$, clay-3 [ $48.2 \%$ clay $+35 \%$ sand], silty-clay loam, and sandy loam). Three soils with different clay contents were included in the experiment, because clay particles provide greater surface area for adsorption of mineral nutrients and hold more water compared with silt and sand particles. Soils were collected from Kazova Plain in Tokat Province. The plants were watered according to their needs to avoid the effects of water stress.

\section{Data Collection}

Seedling Survival and Growth Traits. Seedling survival was recorded in all experiments to calculate the seedling survival rate. Plant height was recorded at 2 wk intervals throughout the experimental duration. Surviving seedlings in each experiment were harvested at 90 DAT. Plants were assessed for their flowering output (FO) before harvest. Plant height was measured at harvest; whole plants with soil were taken out from the pots and thoroughly rinsed. Root length (cm) was measured from the first node to the tip of the longest root. Plants were divided into above- and belowground parts, weighed fresh to determine fresh weight $\left(\mathrm{g}\right.$ plant $\left.{ }^{-1}\right)$, dried separately at $65 \mathrm{C}$ until constant weight, and then weighed to obtain total dry weight $\left(\mathrm{g}\right.$ plant $\left.{ }^{-1}\right)$. Relative growth rate (RGR) was considered as an increase in weight per initial seedling weight per day. Dry weight of harvested seedlings 10 DAT was used in the calculations of RGR. Root and shoot mass ratios (RMR and SMR, respectively) were calculated as a proportion of plant biomass allocated to roots and shoots. Fresh and dry weight ratio (FDR) was obtained by dividing the fresh weight by the dry weight. Root:shoot ratio (RSR) was taken as the ratio of root dry weight to shoot dry weight. The definitions, abbreviations, and units of measured growth traits are summarized in Table 2.

Nutrient Uptake/Accumulation. Aboveground parts of harvested plants were thoroughly rinsed with deionized water, oven dried at $65 \mathrm{C}$, and ground to fine powder. The obtained powder was ashed in the microwave oven and digested in $2 \mathrm{ml} 35 \% \mathrm{H}_{2} \mathrm{O}_{2}$ and 
Table 2. Definitions, abbreviations, and units of growth and nutrient uptake traits recorded in different experiments.

\begin{tabular}{|c|c|c|}
\hline Trait & Description & Unit \\
\hline SP & Survival percentage & $\%$ surviving seedlings \\
\hline RGR & Relative growth rate & $\begin{array}{l}\mathrm{g} \text { plant } \mathrm{g}^{-1}{ }^{\circ} \text { initial } \\
\text { weight } \text { day }^{-1}\end{array}$ \\
\hline FW & Fresh weight & g pot $\operatorname{pot}^{-1}$ \\
\hline DW & Dry weight & g pot ${ }^{-1}$ \\
\hline FDR & Fresh weight dry weight ratio & \\
\hline RMR & Root mass ratio & $\mathrm{g}_{\text {root } \mathrm{g}^{-1} \text { plant }}$ \\
\hline SMR & Shoot mass ratio & g shoot $\mathrm{g}^{-1^{1}}$ plant \\
\hline RSR & Root:shoot ratio & \\
\hline PHh & Plant height at harvest & $\mathrm{cm}$ \\
\hline RL & Root length & $\mathrm{cm}$ \\
\hline $\mathrm{FO}$ & Flowering output & $\%$ flowering plants \\
\hline K (\%) & $\mathrm{K}^{+}$uptake & $\%$ of shoot dry matter \\
\hline $\operatorname{Mg}(\%)$ & $\mathrm{Mg}^{2+}$ uptake & $\%$ of shoot dry matter \\
\hline $\mathrm{Na}(\%)$ & $\mathrm{Na}^{+}$uptake & $\%$ of shoot dry matter \\
\hline $\mathrm{Ca}(\%)$ & $\mathrm{Ca}^{2+}$ uptake & $\%$ of shoot dry matter \\
\hline $\mathrm{P}(\%)$ & P uptake & $\%$ of shoot dry matter \\
\hline $\mathrm{K} / \mathrm{Na}$ & $\mathrm{K}: \mathrm{Na}$ ratio & \\
\hline
\end{tabular}

$5 \mathrm{ml} \mathrm{5 \%} \mathrm{HNO}_{3}$. Following digestions, $\mathrm{K}, \mathrm{Ca}, \mathrm{Mg}$, and $\mathrm{Na}$ were analyzed using an atomic absorption spectrophotometer (AAS, Agilent 24 FS; Bataglia et al. 1983). Phosphorus concentration was recorded by the Barton method (Barton 1948). Nutrient uptake values were converted to percent of the aboveground dry matter. The $\mathrm{K} / \mathrm{Na}$ ratio was calculated by dividing the $\mathrm{K}$ and $\mathrm{Na}$ concentrations.

Statistical Analysis. Only treatments in which all seedlings survived until harvest were included in statistical analyses. In case of drought and salinity experiments, extreme intensities of drought and salinity $\left(12.5 \% \mathrm{FC}\right.$ and $12 \mathrm{dS} \mathrm{m}^{-1}$, respectively) were excluded from analysis, as most of the seedlings died before harvest. Fisher's analysis of variance (ANOVA) technique was used to test significance among experimental runs and treatments. Data from each experiment (drought, salinity, and soil texture) were analyzed separately. First, differences among experimental runs were tested using one-way ANOVA. Due to the nonsignificant effect of time, data of experimental runs were combined, so the final analyzed data had 10 replications. Second, differences among treatments were tested for each type of experiment. Differences among treatment means were tested using a least-significance difference test (LSD) at a 5\% probability level where ANOVA indicated significant differences. The correlation between growth and nutrient uptake traits was also tested using a two-tailed Pearson correlation. Finally, polynomial regression was fitted (for drought and salinity experiments) to illustrate the data on plant height, seedling survival, and flowering output in graphical form.

\section{Results and Discussion}

Drought Stress. Drought stress significantly affected ragweed seedling survival (Figures 1a, 2a, and 3a; Table 3). Plants tolerated drought up to $25 \% \mathrm{FC}$, whereas most of the seedlings died under an extreme level of drought stress (Figure 2a). Seedling recruitment and survival are the key contributors to successful plant invasion (Blackburn et al. 2013, 2015; Simberloff 2009), and introduction of higher numbers of
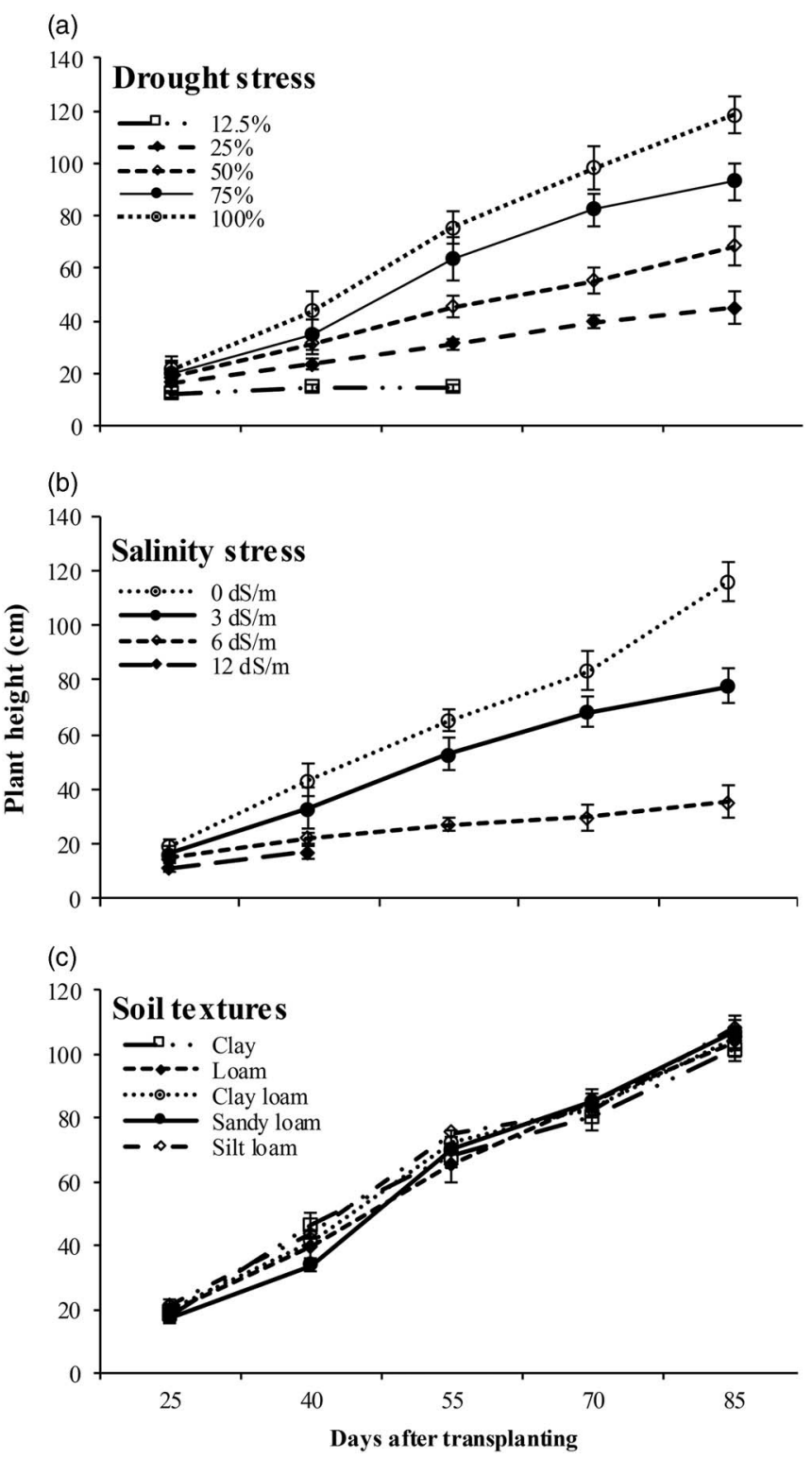

Figure 1. Effect of (a) drought intensities, (b) salinity levels, and (c) soil textures on plant height $(\mathrm{cm})$ of common ragweed $(\mathrm{n}=10)$. 

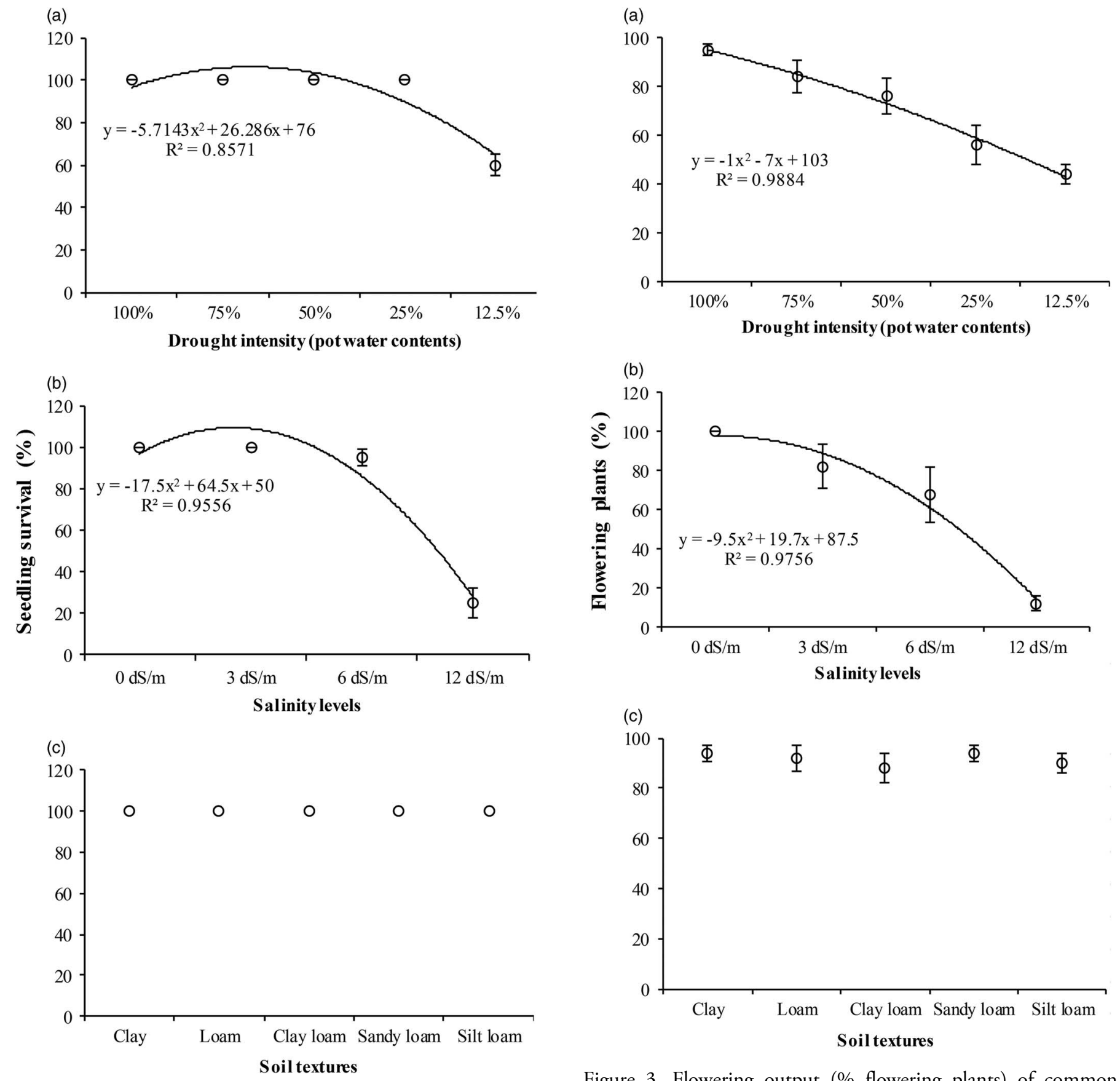

Figure 2. Seedling survival (\%) of common ragweed under different (a) drought intensities, (b) salinity levels, and (c) soil textures $(\mathrm{n}=10)$.

seedlings maximizes the chances of spread and invasion to new habitats (Caswell et al. 2003). Our study shows that successful seedling recruitment and survival, even under harsh environments, are responsible for conferring invasiveness in ragweed (Figure 2a). Leiblein and Losch (2011) have also reported similar results.

Abiotic stresses, particularly salinity and drought, suppress plant growth from seedling to maturity and hamper fresh and dry biomass allocation to leaves, stems, and roots (Yang et al. 2006). Rapid growth rate

Figure 3. Flowering output (\% flowering plants) of common ragweed under different (a) drought intensities, (b) salinity levels, and $(\mathrm{c})$ soil textures $(\mathrm{n}=10)$.

and higher biomass accumulation are proposed as main contributing traits to successful invasions of varying habitats (Burns 2004, 2006; Dawson et al. 2011). The root system is the primary determinant of water and nutrient uptake and biomass allocation in plants (Bernstein and Kafkafi 2002). Drought intensities significantly affected the growth and nutrient uptake traits of ragweed except for FDR, RMR, SMR, RSR, K uptake, and $\mathrm{K} / \mathrm{Na}$ ratio (Table 3). Increasing drought intensity significantly reduced RGR, FW, DW, PHh,

Onen et al.: Ragweed tolerance to abiotic stresses . 
Table 3. Analysis of variance for growth and nutrient uptake traits of ragweed grown under different drought intensities, salinity levels, and soil textures.

\begin{tabular}{|c|c|c|c|c|c|c|c|c|c|}
\hline Trait & \multicolumn{3}{|c|}{ Drought } & \multicolumn{3}{|c|}{ Salinity } & \multicolumn{3}{|c|}{ Soil textures } \\
\hline RGR & 0.566 & 66.0 & $0.000^{* * *}$ & 0.069 & 257 & $0.000^{* * *}$ & 0.0218 & 1.77 & $0.1578^{\mathrm{NS}}$ \\
\hline DW & 4144.60 & 67.4 & $0.000^{* * *}$ & 431.07 & 235 & $0.000^{* * *}$ & 229.73 & 2.55 & $0.0566^{\mathrm{NS}}$ \\
\hline FDR & 8.44 & 2.06 & $0.128^{\mathrm{NS}}$ & 0.569 & 0.58 & $0.579^{\mathrm{NS}}$ & 17.70 & 7.77 & $0.0001^{* * *}$ \\
\hline RMR & 0.047 & 2.74 & $0.061^{\mathrm{NS}}$ & 0.035 & 9.17 & $.006^{* *}$ & 0.0109 & 1.45 & $0.2348^{\mathrm{NS}}$ \\
\hline RSR & 0.009 & 0.34 & $0.796^{\mathrm{NS}}$ & 0.098 & 3.05 & $0.050^{*}$ & 0.11 & 5.57 & $0.0014^{* * *}$ \\
\hline $\mathrm{PHh}$ & 22412.0 & 68.4 & $0.000^{* * *}$ & 12989.8 & 60.10 & $0.000^{* * *}$ & 140.4 & 0.11 & $0.9766^{\mathrm{NS}}$ \\
\hline $\mathrm{RL}$ & 2054.92 & 8.76 & $0.000^{* * *}$ & 408.33 & 0.87 & $0.451^{\mathrm{NS}}$ & 548.70 & 2.86 & $0.0376^{*}$ \\
\hline $\mathrm{K}(\%)$ & 2.86 & 1.13 & $0.355^{\mathrm{NS}}$ & 0.284 & 0.30 & $0.751^{\mathrm{NS}}$ & 0.545 & 0.78 & $0.5443^{\mathrm{NS}}$ \\
\hline $\mathrm{Na}(\%)$ & 0.002 & 3.22 & $0.0376^{*}$ & 1.627 & 205 & $0.000^{* * *}$ & 0.0052 & 4.61 & $0.0043^{* *}$ \\
\hline $\mathrm{Ca}(\%)$ & 0.615 & 14.2 & $0.000^{* * *}$ & 0.021 & 0.40 & $0.682^{\mathrm{NS}}$ & 0.4076 & 4.44 & $0.0052^{* *}$ \\
\hline
\end{tabular}

${ }^{\text {a }}$ Significant at: ${ }^{*} \mathrm{P} \leq 0.05 ;{ }^{* *} \mathrm{P} \leq 0.01 ;{ }^{* * *} \mathrm{P} \leq 0.001 ; \mathrm{NS}$, nonsignificant.

b SS, sum of squares.

$\mathrm{RL}$, and $\mathrm{Na}, \mathrm{Mg}, \mathrm{Ca}$, and $\mathrm{P}$ accumulation (Table 4). Moreover, a linear reduction in FW, DW, RGR, $\mathrm{PHh}$, and RL was observed with increasing drought intensity. Increasing drought stress had nonsignificant effects on biomass allocation of plants toward roots and shoots, which could explain the invasion success of ragweed. Mechanical impedance of soil is responsible for retarding root length under drought stress. Reduction in root elongation of different plants under drought stress has been well explicated
(Bengough et al. 2011; Sarangi et al. 2016). Ragweed displays stronger aboveground than belowground competitive ability under interspecific competition (Leskovšek et al. 2012a). Similar results were obtained in the current study, as ragweed allocated more biomass to aboveground compared with belowground strata.

The highest $\mathrm{Mg}$ and $\mathrm{Ca}$ concentrations were observed under mild drought, while the highest $\mathrm{P}$ concentration was noted under moderate drought

Table 4. Growth and nutrient uptake response of ragweed to different drought intensities.

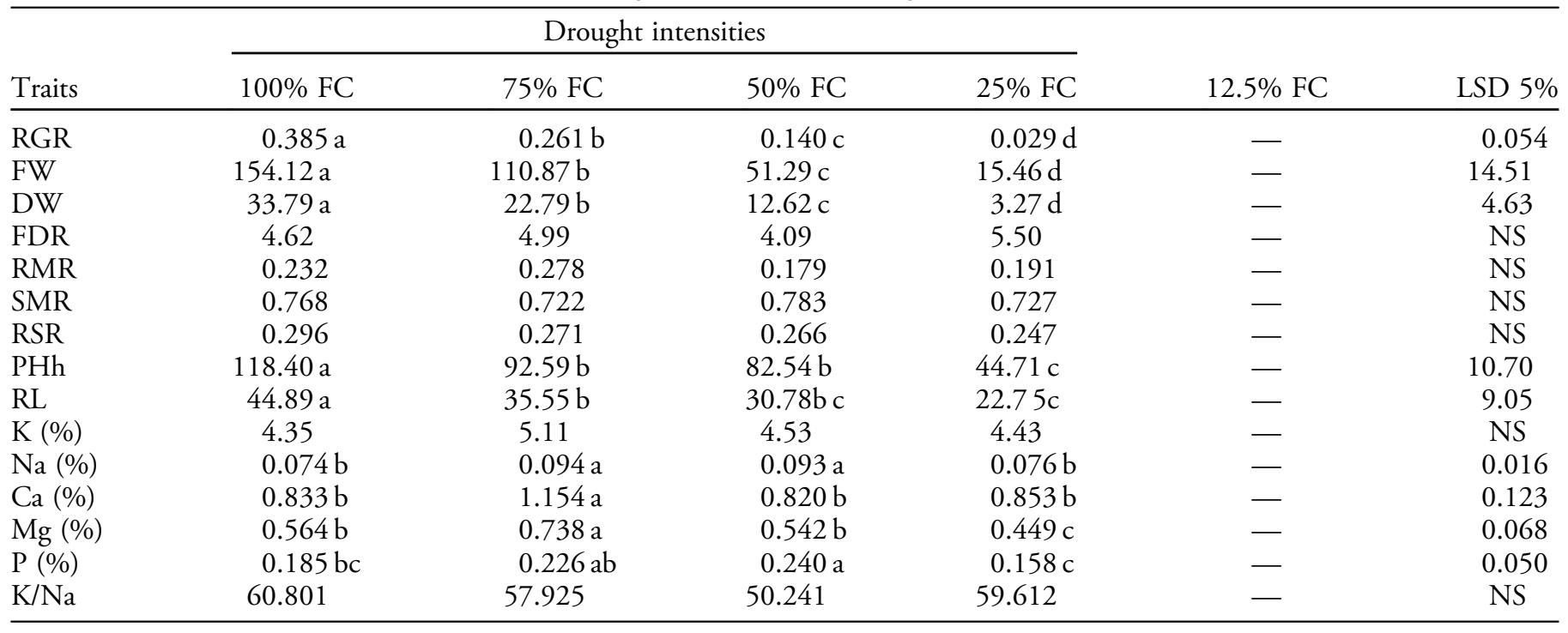

Means followed by different letters within a row are significantly $(\mathrm{P} \leq 0.05)$ different from each other. Dash $(-)$ indicates treatments excluded from statistical analysis. NS, nonsignificant. 
stress. However, there were no significant differences in nutrient accumulation under remaining drought intensities (Table 4). Flowering output was significantly affected by drought stress, and linear reduction in $\mathrm{FO}$ was observed with increasing drought intensity $\left(\mathrm{R}^{2}=0.98\right.$; Figure $\left.3 \mathrm{a}\right)$.

Different growth and nutrient uptake traits had significant correlations at $\mathrm{P} \leq 0.05$ or $\mathrm{P} \leq 0.01$ levels (Table 5) under drought stress. RGR, FW, and DW were positively correlated with one another and with RMR, PHh, RL, and Mg uptake (Table 5), whereas FDR had negative correlation with RMR and SMR. Although RL had positive correlation with growth traits, no significant correlation was observed with nutrient acquisition traits (Table 5). The $\mathrm{K}$ uptake had negative correlation with $\mathrm{Na}$ and positive correlation with $\mathrm{Ca}$ uptake and $\mathrm{K} / \mathrm{Na}$ ratio.

Nutrient acquisition not only helps plants to maintain a superior growth but also improves tolerance to abiotic stresses. Potassium is essential for protein synthesis, photosynthesis, stomatal regulation, and osmoregulation, and therefore plays a key role in drought tolerance. Increased drought resistance of crop plants through $\mathrm{K}$ application has been cited in different studies (Ahmad et al. 2015; Sangakkara et al. 2001). Lower availability of moisture decreases $\mathrm{K}$ inflow in plants, and wilting under drought stress suggests possible K deficiency (Beringer and Trolldenier 1978). No differences for $\mathrm{K}$ uptake among different drought intensities in the current study suggest that ragweed has evolved phenotypic plasticity for higher $\mathrm{K}$ uptake to alleviate the adverse effects of drought stress.

Ragweed invasion in temperate regions is well studied, and temperature is considered the main limiting climatic factor in its further spread (Essl et al. 2015; Skalova et al. 2015). However, further spread in the semiarid regions will not solely be limited by temperature; drought and salinity will also play a significant role. Although high and moderate rainfall areas of Turkey are currently under ragweed invasion (Onen et al. 2014, 2015; Ozaslan et al. 2016), observed phenotypic plasticity for growth, biomass accumulation, and nutrient uptake under drought stress suggest that semiarid and partly arid areas of the country are at risk for ragweed invasion. Moreover, similar results are expected for ragweed invasion in semiarid regions in the rest of the world.

Salinity Stress. Ragweed was found tolerant to

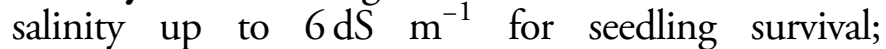
no transplanted seeds survived beyond this level.

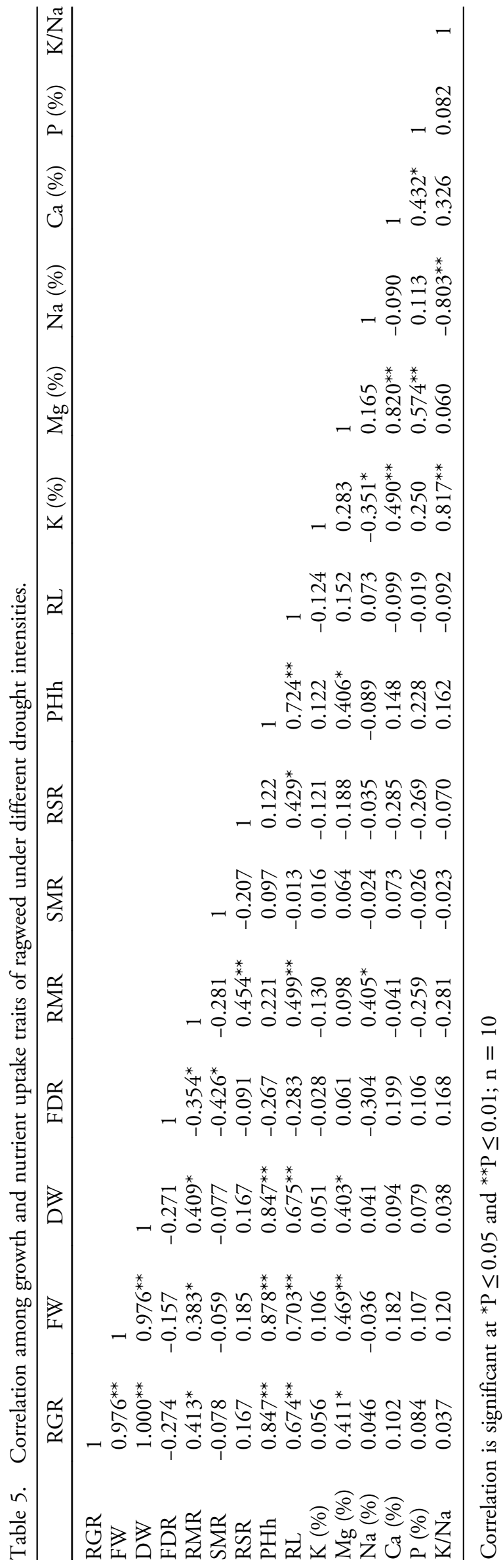

Onen et al.: Ragweed tolerance to abiotic stresses 
Different salinity levels significantly affected the growth and nutrient uptake traits, except FDR, RL and $\mathrm{K}$, and $\mathrm{Mg}$ and $\mathrm{Ca}$ uptake (Table 3; Figures $\mathrm{b}$, $2 \mathrm{~b}$, and $3 \mathrm{~b}$ ). Flowering output and plant height were gradually decreased up to $3 \mathrm{dS} \mathrm{m}$; a further increase in salinity resulted in a sharp decline. However, increasing the salinity level to $3 \mathrm{dS} \mathrm{m}^{-1}$ did not affect seedling survival, whereas seedling survival and reproductive output were notably reduced under higher salinity levels (Figures $1 \mathrm{~b}$ and $2 \mathrm{~b}$ ). The highest and the lowest seedling survival and plant height were recorded under no and extreme salinity, respectively, and some seedlings managed to survive and flower under extreme salinity (Figure 2b). Seedling survival plays a key role in plant invasion, as introduction with a higher number of individuals increases the likelihood of successful invasions, whereas inability to adapt to new environments results in failed invasions (Blackburn et al. 2013, 2015). Seedling survival up to a certain salinity level indicates that ragweed is sensitive to high salinity. However, it can tolerate moderate salinity, suggesting that the plant has the potential to invade relatively saline soils. Survival of ragweed seedlings under saline conditions has also been partially explained by DiTommaso (2004).

Growth traits such as RGR, FW, DW, FDR, RMR, RSR, PHh, and RL, and nutrient uptake traits such as $\mathrm{P}$ accumulation and $\mathrm{K} / \mathrm{Na}$ ratio decreased linearly with increasing salinity (Table 6). Salinity induced a significant increase in plant $\mathrm{Na}$ content, and the highest SMR and $\mathrm{Na}$ uptake were observed under severe salinity (Table 6). The highest and lowest $\mathrm{K} / \mathrm{Na}$ ratio was observed under no and severe salinity, respectively. However, $\mathrm{Mg}$ and $\mathrm{Ca}$ content behaved differently in response to increasing salinity compared with other nutrients (Table 6). FO was sharply decreased with increased salinity $\left(\mathrm{R}^{2}=0.95\right.$; Figure $\left.3 \mathrm{~b}\right)$.

RGR, FW, and DW levels were positively correlated with one another and RMR, RSR, PHh, $\mathrm{P}$ uptake, and $\mathrm{K} / \mathrm{Na}$ ratio and negatively correlated with SMR and $\mathrm{Na}$ uptake under salinity stress (Table 7). Sodium accumulation was negatively correlated with all growth traits except SMR, indicating that higher accumulation of Na hampers growth traits (Table 7). Phosphorus uptake and $\mathrm{K} / \mathrm{Na}$ ratio were positively correlated with each other and all growth traits except SMR and FDR but negatively correlated with $\mathrm{Na}$ accumulation (Table 7). This indicates that maintaining a high $\mathrm{K} / \mathrm{Na}$ ratio alleviates the negative effects of salinity on growth and development of ragweed.

Soil salinity is a major limitation to the survival and growth of many plant species. Ragweed tolerated
Table 6. Growth and nutrient uptake response of ragweed to different salinity levels

\begin{tabular}{|c|c|c|c|c|c|}
\hline \multirow[b]{2}{*}{ Traits } & \multicolumn{4}{|c|}{ Salinity treatments } & \multirow[b]{2}{*}{ LSD } \\
\hline & Control & $3 \mathrm{dSm}^{-1}$ & $6 \mathrm{dSm} \mathrm{m}^{-1}$ & $12 \mathrm{dSm}^{-1}$ & \\
\hline RGR & $0.205 \mathrm{a}$ & $0.103 \mathrm{~b}$ & $0.019 \mathrm{c}$ & - & 0.018 \\
\hline FW & $72.71 \mathrm{a}$ & $40.00 \mathrm{~b}$ & $8.30 \mathrm{c}$ & - & 8.44 \\
\hline DW & $16.47 \mathrm{a}$ & $8.31 \mathrm{~b}$ & $1.82 \mathrm{c}$ & - & 1.53 \\
\hline FDR & 4.42 & 4.84 & 4.91 & - & NS \\
\hline RMR & $0.292 \mathrm{a}$ & $0.293 \mathrm{a}$ & $0.178 \mathrm{~b}$ & - & 0.069 \\
\hline SMR & $0.708 \mathrm{~b}$ & $0.707 \mathrm{~b}$ & $0.822 \mathrm{a}$ & - & 0.069 \\
\hline RSR & $0.427 \mathrm{a}$ & $0.387 \mathrm{ab}$ & $0.218 \mathrm{~b}$ & - & 0.203 \\
\hline PHh & $116.05 \mathrm{a}$ & $77.15 b$ & $35.48 \mathrm{c}$ & - & 16.63 \\
\hline $\mathrm{RL}$ & 51.73 & 39.68 & 39.05 & - & NS \\
\hline K (\%) & 3.08 & 3.09 & 2.76 & - & NS \\
\hline $\mathrm{Na}(\%)$ & $0.110 \mathrm{c}$ & $0.318 \mathrm{~b}$ & $0.974 \mathrm{a}$ & - & 0.100 \\
\hline $\mathrm{Ca}(\%)$ & 0.849 & 0.950 & 0.882 & - & NS \\
\hline $\operatorname{Mg}(\%)$ & 0.520 & 0.533 & 0.507 & - & NS \\
\hline P (\%) & $0.413 \mathrm{a}$ & $0.285 \mathrm{ab}$ & $0.207 \mathrm{~b}$ & - & 0.161 \\
\hline $\mathrm{K} / \mathrm{Na}$ & $28.75 \mathrm{a}$ & $9.75 \mathrm{~b}$ & $2.87 \mathrm{~b}$ & - & 8.76 \\
\hline
\end{tabular}

Means followed by different letters within a row are significantly $(\mathrm{P} \leq 0.05)$ different from each other. Dash $(-)$ indicates treatments excluded from statistical analysis. NS, nonsignificant.

moderate salinity by decreasing plant height, biomass production, and growth rate (Table 6). Several other weeds such as yellow-horn (Xanthoceras sorbifolia Bunge, orth var.), Kashgar tamarisk (Tamarix hispida Willd.), and five-stamen tamarisk (Tamarix chinesis Lour.) have evolved the same mechanisms for drought and salinity tolerance (Dong and Yue 2010; Liu et al. 2014; Xie et al. 2010).

The resource-capturing ability of plants depends on the pattern of biomass allocation to roots and shoots (Grime 2001; Poorter et al. 1990). Biomass allocation and its plasticity significantly differ among different plant species under various environmental conditions (Aikio and Markkola 2002; McConnaughay and Coleman 1999). Our study indicates that ragweed allocated higher biomass to aboveground strata compared with belowground under increased salinity levels. Leskovšek et al. (2012b) reported that ragweed allocates more biomass toward upper strata under nitrogen stress. Hence, our results coincide well with these earlier findings.

The root system was negatively affected by increasing salinity, mainly due to the high salt concentration in the root zone causing ion toxicity. Several studies concluded that salinity stress hampers the root elongation rate of several plant species (Jbir et al. 2001; Liu et al. 2014; Zhu et al. 1998). The root system plays a vital role in nutrient and water uptake and thus determines the success or 


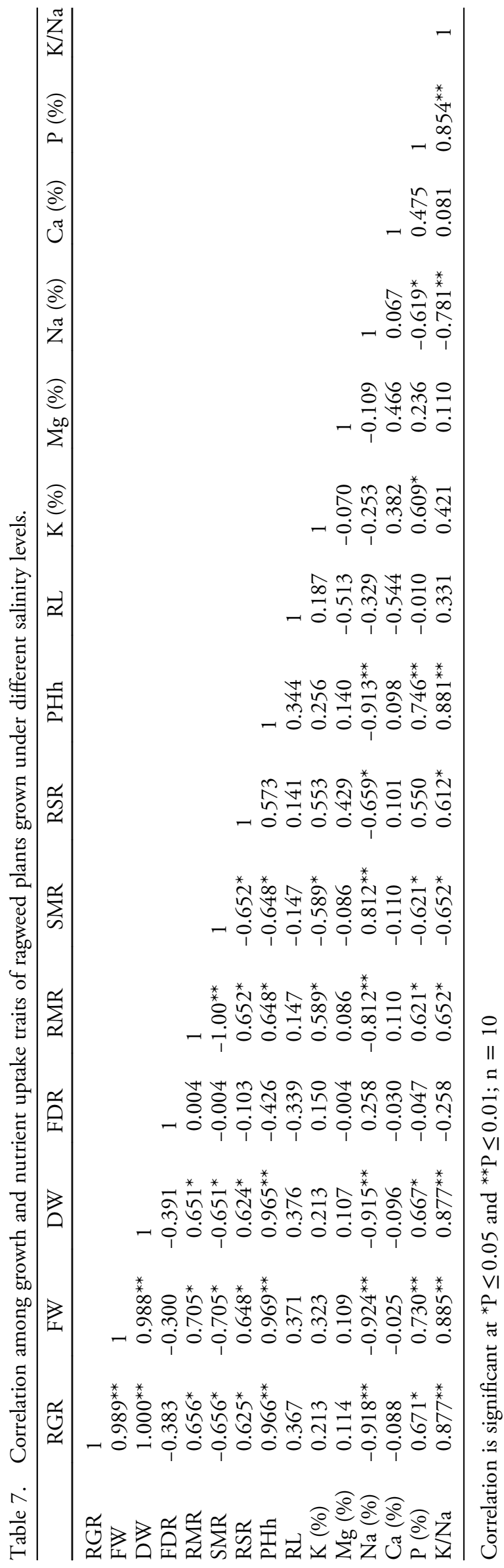

failure of plants under various environmental gradients. The differences in nutrient uptake are due to poor root system development under high salinity.

Potassium is a competitor of $\mathrm{Na}$ under salinity stress, and maintenance of high $\mathrm{K} / \mathrm{Na}$ ratio improves salinity tolerance (Asch et al. 2000). The $\mathrm{K} / \mathrm{Na}$ ratio was significantly influenced by soil salinity, decreasing with increasing salinity. Ioneva (1988) reported that higher $\mathrm{Na}$ and lower $\mathrm{K}$ contents in plant leaves are result of competition between $\mathrm{Na}$ and $\mathrm{K}$ ions on the absorptive sites of the plant roots. The sharp decline in $\mathrm{K} / \mathrm{Na}$ ratio and its positive correlation with growth traits and negative correlation with $\mathrm{Na}$ indicate that ragweed is sensitive to salinity beyond $3 \mathrm{dS} \mathrm{m}$. Sodium is not an essential element for plant growth, and it accumulates in plants at the expense of $\mathrm{Ca}$ and $\mathrm{K}$ under saline conditions (Kuiper 1984). Excessive $\mathrm{Na}$ in the external solution decreases $\mathrm{K}$ and $\mathrm{Ca}$ uptake in many plant species (Hu and Schmidhalter 2001). No change in $\mathrm{Mg}$ and $\mathrm{Ca}$ concentrations under different salinity levels suggest that ragweed was unable to cope with higher salinity, as more $\mathrm{Na}$ was accumulated than $\mathrm{K}, \mathrm{Mg}$, and $\mathrm{Ca}$ under higher salinity. Greenway and Munns (1980) also indicated that plants must obtain relatively high concentrations of $\mathrm{Ca}$ and $\mathrm{K}$ to grow successfully on saline soils.

Phosphorus absorption is reduced under high salinity, as precipitation of phosphate ions occurs with $\mathrm{Ca}, \mathrm{Mg}$, and $\mathrm{Zn}$ ions, which makes $\mathrm{P}$ unavailable to plants (Rewald et al. 2013). Decrease in P uptake under drought and saline conditions corresponds well to these findings. The adaptability of ragweed populations to low-saline soil conditions has also been reported earlier (DiTommaso 2004; Eom et al. 2013).

Soil Textures. Soil types included in this study had a wide range of clay and sand content (Table 1). Clay particles are responsible for many physical and chemical behaviors of soils and are important to determine soil hydrologic qualities and nutrient availability (Eshel et al. 2004). Soil textures had a slight effect on growth and a significant effect on nutrient uptake (except K; Table 3; Figures 1c, 2c, and 3c). Most of the growth traits evaluated were not affected by the changes in soil texture, which is an indication that ragweed can adapt to various soil textures.

Ragweed plants grown on sandy-loam soil had the highest RGR, DW, and SMR. However, there were no differences among soil textures for these traits, except with soil having high clay content (Table 8).

Onen et al.: Ragweed tolerance to abiotic stresses •

123 
Table 8. Growth and nutrient uptake response of ragweed to soil textures.

\begin{tabular}{lcccccc}
\hline & \multicolumn{5}{c}{ Soil textures } & \\
\cline { 2 - 5 } Traits & Clay-1 & Clay-2 & Clay-3 & Silty-clay loam & Sandy loam & LSD 5\% \\
\hline RGR & $0.20 \mathrm{~b}$ & $0.23 \mathrm{ab}$ & $0.23 \mathrm{ab}$ & $0.22 \mathrm{ab}$ & $0.27 \mathrm{a}$ & 0.056 \\
FW & 95.01 & 95.57 & 95.11 & 96.76 & 95.75 & $\mathrm{NS}$ \\
DW & $18.57 \mathrm{~b}$ & $20.65 \mathrm{ab}$ & $24.22 \mathrm{a}$ & $19.98 \mathrm{ab}$ & $24.63 \mathrm{a}$ & 4.82 \\
FDR & $5.14 \mathrm{a}$ & $4.69 \mathrm{ab}$ & $3.30 \mathrm{c}$ & $4.86 \mathrm{a}$ & $4.00 \mathrm{bc}$ & 0.76 \\
RMR & 0.173 & 0.169 & 0.174 & 0.17 & 0.13 & $\mathrm{NS}$ \\
SMR & $0.826 \mathrm{~b}$ & $0.83 \mathrm{ab}$ & $0.84 \mathrm{ab}$ & $0.83 \mathrm{ab}$ & $0.87 \mathrm{a}$ & 0.044 \\
RSR & $0.20 \mathrm{bc}$ & $0.20 \mathrm{bc}$ & $0.30 \mathrm{a}$ & $0.21 \mathrm{~b}$ & $0.14 \mathrm{c}$ & 0.07 \\
PHh & 94.58 & 91.03 & 90.28 & 90.08 & 89.17 & $\mathrm{NS}$ \\
RL & $38.35 \mathrm{a}$ & $29.32 \mathrm{~b}$ & $29.21 \mathrm{~b}$ & $35.60 \mathrm{ab}$ & $30.51 \mathrm{~b}$ & 7.02 \\
K (\%) & 2.56 & 2.62 & 2.89 & 2.61 & 2.66 & $\mathrm{NS}$ \\
Na (\%) & $0.10 \mathrm{a}$ & $0.07 \mathrm{~b}$ & $0.07 \mathrm{~b}$ & $0.09 \mathrm{ab}$ & $0.09 \mathrm{a}$ & 0.01 \\
Ca (\%) & $1.04 \mathrm{a}$ & $0.75 \mathrm{c}$ & $0.83 \mathrm{bc}$ & $0.93 \mathrm{ab}$ & $0.82 \mathrm{bc}$ & 0.15 \\
$\mathrm{Mg}(\%)$ & $1.61 \mathrm{a}$ & $0.90 \mathrm{~b}$ & $0.56 \mathrm{c}$ & $1.02 \mathrm{ab}$ & $0.86 \mathrm{~b}$ & 0.17 \\
P (\%) & $0.29 \mathrm{~b}$ & $0.28 \mathrm{~b}$ & $0.18 \mathrm{c}$ & $0.25 \mathrm{~b}$ & $0.34 \mathrm{a}$ & 0.4 \\
K/N a & $25.20 \mathrm{c}$ & $34.30 \mathrm{ab}$ & $40.58 \mathrm{a}$ & $29.73 \mathrm{bc}$ & $29.70 \mathrm{bc}$ & 8.71 \\
\hline
\end{tabular}

Means followed by different letters within a row are significantly $(\mathrm{P} \leq 0.05)$ different from each other. NS, nonsignificant.

Plants grown in high-clay and silty-clay loam soil had the longest roots compared with plants grown in soils with other textures (Table 8). These results indicate that ragweed can successfully grow and reproduce on soils with various soil textures. Bassett and Crompton (1975) reported that ragweed prefers clay soil, and its nonselective nature regarding soil texture has also been partially explained by Fumanal et al. (2008). Ragweed is an opportunistic species invading both nutrient-rich and disturbed and nutrient-poor habitats (Leskovšek et al. 2012a; Pysek et al. 2012). Ragweed was found to be nonselective for soil texture in the current study, and these results correspond well with Fumanal et al. (2008).

The trend of nutrient uptake varied with changing soil texture (Table 8). Clay particles are the most active component of soil texture due to their high surface area and related negative charges. Plants grown on high-clay and silty-clay loam soils accumulated more $\mathrm{Mg}$ and $\mathrm{Ca}$, while higher $\mathrm{P}$ gain was noted on sandy-loam soil (Table 8). Higher cation exchange capacity of clay soils probably led to the accumulation of alkali earth cations in plants. However, P can be tightly adsorbed on the surface and interlayers of clay minerals, which may reduce the phytoavailability of $\mathrm{P}$ in soil. The highest $\mathrm{K} / \mathrm{Na}$ ratio was observed in silty-loam soil, and the lowest in high-clay soil (Table 8).

Growth and nutrient uptake traits of ragweed grown under different soil textures had significant correlations (Table 9). RGR was positively correlated with DW and negatively correlated with FDR and
RL. FW had positive correlations with FDR, RMR, and RSR and negative correlation with SMR and P uptake. Potassium uptake was negatively correlated with $\mathrm{Ca}$ and $\mathrm{Mg}$, while $\mathrm{Na}$ uptake was positively correlated with $\mathrm{Ca}$ and $\mathrm{Mg}$. Similarly, P uptake was negatively and positively correlated with FW, RSR, and $\mathrm{Mg}$, respectively (Table 9).

Soil physical conditions relating to soil texture and structure can limit both root and shoot growth due to restricted root penetration to the lower part of the soil profile (Bengough et al. 2011), unavailability of mineral nutrients (fixation by clay minerals), low water-holding capacity (in sandy soils), and low aeration due to the fine size of clay particles. Growth traits of ragweed were slightly affected by variations in soil texture. Soils with highest clay and sand content were significantly different for RGR $(0.20$ and 0.27 for clay- $1[67.7 \%$ clay] and sandy-loam [47.3\% sand]) soils, respectively.

Ragweed's tolerance of severe drought and moderate salinity and its nonselective nature with respect to soil texture suggest that the plant has an extensive adaptive potential for semiarid to partially arid regions. Extreme drought and salinity stresses can reduce propagation pressure and affect population dynamics. Further, as drought and salinity might play an important role in further range expansion, these must be considered while modeling the current and future distribution of ragweed in Turkey and in other arid and semiarid regions of the world. Nonetheless, modeling studies to map potential distribution areas of ragweed under current 


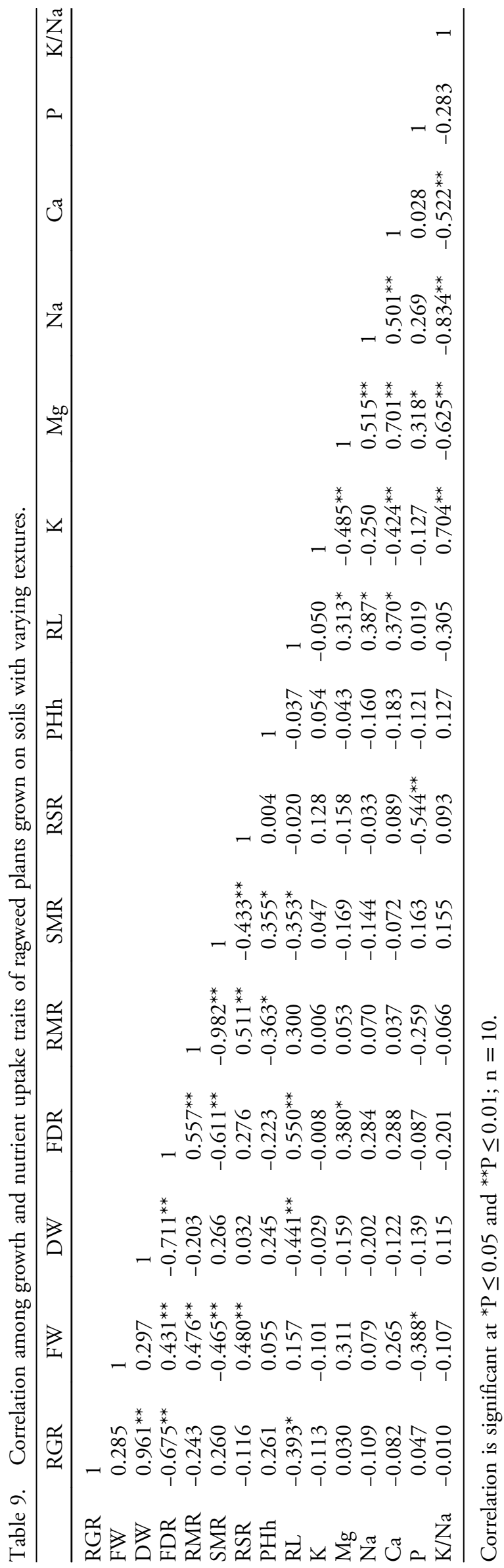

and future climate scenarios are urgently needed to predict future range expansion. Based on the current findings, it is recommended that early warnings to stop further invasion of ragweed in Turkey be issued.

\section{Acknowledgments}

This study was supported by the Scientific and Technological Council of Turkey (TUBITAK) through grant number $113 \mathrm{O} 790$ as a part of COST Action (TD 1209, European Information System for Alien Species). The results presented here also address one of the major challenges focused by COST Action FA 1203 (Sustainable Management of Ambrosia artemisiifolia in Europe). SF extends thanks to TUBITAK for supporting his $\mathrm{PhD}$ studies. Thanks are due to Sonnur TAD for her technical help throughout the course of the studies.

\section{Literature Cited}

Ahmad N, Khan MB, Farooq S, Shahzad M, Farooq M, Hussain M (2015) Potassium nutrition improves the maize productivity under water deficit conditions. Soil Environ 34:15-26

Aikio S, Markkola AM (2002) Optimality and phenotypic plasticity of shoot-to-root ratio under variable light and nutrient availability. Evol Ecol 16:67-76

Araujo MB, Alagador D, Cabeza M, Nogues-Bravo D, Thuiller W (2011) Climate change threatens European conservation areas. Ecol Lett 14:484-492

Arslan ZF, Uludag A, Uremis I (2015) Status of invasive alien plants included in EPPO Lists in Turkey. EPP/EPPO Bulletin 45:66-72

Asch F, Dingkuhn M, Miezan K, Dörffling K (2000) Leaf K/Na ratio predicts salinity induced yield loss in irrigated rice. Euphytica 113:109-118

Barton CJ (1948) Photometric analysis on phosphate rock. Ind Anal Eng Chem 20:1068-1073

Bassett IJ, Crompton CW (1975) The biology of Canadian Weeds. 11. Ambrosia artemisiifolia L. and A. psilostachya DC. Can J Plant Sci 55:463-476

Bataglia OC, Furlani AMC, Teixeira JPF, Furlani PR, Gallo JR (1983) Métodos de análise química de plantas. Brazil: Instituto Agronomico, Campinas

Bengough AG, McKenzie BM, Hallett PD, Valentine TA (2011) Root elongation, water stress, and mechanical impedance: a review of limiting stresses and beneficial root tip traits. J Exp Bot 62:59-68

Beringer H, Trolldenier G (1978) Influence of K nutrition on the response to environmental stress. Pages 189-222 in Proceedings of the 11th Congress of the International Potash Institute. Bern, Switzerland: International Potash Institute

Bernstein N, Kafkafi U (2002) Root growth under salinity stress. Pages 787-819 in Waisel Y, Eshel A, Kafkafi U, eds. Plant Roots: The Hidden Half. 3rd edn. New York: Dekker

Blackburn TM, Lockwood JL, Cassey P (2015) The influence of numbers on invasion success. Mol Ecol 24:1942-1953

Blackburn TM, Prowse TAA, Lockwood JL, Cassey P (2013) Propagule pressure as a driver of establishment success in deliberately introduced exotic species: fact or artefact? Biol Invasions 15:1459-1469

Onen et al.: Ragweed tolerance to abiotic stresses •

125 
Brauer J, Geber MA (2002) Population differentiation in the range expansion of a native maritime plant, Solidago sempervirens L. Int J Plant Sci 163:141-150

Burns JH (2004) A comparison of invasive and noninvasive dayflowers (Commelinaceae) across experimental nutrient and water gradients. Divers Distrib 10:387-397

Burns JH (2006) Relatedness and environment affect traits associated with invasive and noninvasive introduced Commelinaceae. Ecol Appl 16:1367-1376

Byfield A, Baytop A (1998) Three alien species new to the flora of Turkey. Turk J Bot 22:205-208

Caswell H, Lensink R, Neubert MG (2003) Demography and dispersal: life table response experiments for invasion speed. Ecology 84:1968-1978

Chapman DS, Haynes T, Beal S, Essl F, Bullock JM (2014) Phenology predicts the native and invasive range limits of common ragweed. Glob Chang Biol 20:192-202

Chauhan BS (2013) Growth response of itchgrass (Rottboellia cochinchinensis) to water stress. Weed Sci 61:98-103

Chauhan BS, Johnson DE (2010) Growth and reproduction of jungle rice (Echinochloa colona) in response to water-stress. Weed Sci 58:132-135

Chown SL, Hodgins KA, Griffin PC, Oakeshott JG, Byrne M, Hoffmann AA (2015) Biological invasions, climate change and genomics. Evol Appl 8:23-46

Chrenova J, Micieta K, Scevkova J (2009) Monitoring of Ambrosia pollen concentration in the atmosphere of Bratislava (Slovakia) during years 2002-2007. Aerobiologia 26:83-88

Cuin TA, Miller AJ, Laurie SA, Leigh R A (2003) Potassium activities in cell compartments of salt-grown barley leaves. J Exp Bot 54:657-661

Davenport RJ, Tester M (2000) A weakly voltage-dependent, nonselective cation channel mediates toxic sodium influx in wheat. Plant Physiol 122:823-834

Davidson AM, Jennions M, Nicotra AB (2011) Do invasive species show higher phenotypic plasticity than native species and, if so, is it adaptive? A meta-analysis. Ecol Lett 14:419-431

Davis MA, Grime JP, Thompson K (2000) Fluctuating resources in plant communities: a general theory of invasibility. J Ecol 88:528-534

Dawson TP, Jackson ST, House JI, Prentice IC, Mace GM (2011) Beyond predictions: biodiversity conservation in a changing climate. Science 332:53-58

DiTommaso A (2004) Germination behavior of common ragweed (Ambrosia artemisiifolia) populations across a range of salinities. Weed Sci 52:1002-1009

Dong XH, Yue GZH (2010) Effects on growth of Tamarix hispida Willd. under salt stress. Acta Agric Bor Sin 25:154-155

Eom SH, DiTommaso A, Weston LA (2013) Effects of soil salinity in the growth of Ambrosia artemisiifolia biotypes collected from roadside and agricultural field. J Plant Nutr 36:2191-2204

Eshel G, Levy J, Mingelgrin U, Singer MJ (2004) Critical evaluation of the use of laser diffraction for particle-size distribution analysis. Soil Sci Soc Am J 68:736-743

Essl F, Biró K, Brandes D, Broennimann O, Bullock JM, Chapman DS, Chauvel B, Dullinger S, Fumanal B, Guisan A, Karrer G, Kazinczi G, Kueffer C, Laitung B., Lavoie C, Leitner M, Mang T, Moser D, Müller-Schärer H, Petitpierre B, Richter R, Schaffner U, Smith M, Starfinger U, Vautard R, Vogl G, von der Lippe M, Follak S (2015) Biological flora of the British Isles: Ambrosia artemisiifolia. J Ecol 104:1069-1098
Fumanal B, Girod C, Fried G, Bretagnolle F, Chauvel B (2008) Can the large ecological amplitude of Ambrosia artemisiifolia explain its invasive success in France? Weed Res 48:349-359

Greenway H, Munns R (1980) Mechanisms of salt tolerance in nonhalophytes. Annu Rev Psychol 31:149-190

Grime JP (2001) Plant Strategies and Vegetation Processes and Ecosystem Properties, 2nd edn. Chichester, UK: Wiley

Hellmann JJ, Byers JE, Bierwagen BG, Dukes JS (2008) Five potential consequences of climate change for invasive species. Conserv Biol 22:534-543

$\mathrm{Hu}$ Y, Schmidhalter U (2001) Effects of salinity and macronutrient levels on micronutrients in wheat. J Plant Nutr 24:273-281

Hulme PE, Pyšek P, Jarošík V, Pergl J, Schaffner U, Vila M (2013) Bias and error in understanding plant invasion impacts. Trends Ecol Evol 28:212-218

Ioneva ZS (1988) Effect of potassium ion $\mathrm{Na}^{+}$uptake by plants in conditions of chloride salinity. Fiziolo Rasten 14:42-47

Jbir N, Chaibi W, Ammar S, Jemmali A, Ayadi A (2001) Root growth and lignification of two wheat species differing in their sensitivity to $\mathrm{NaCl}$, in response to salt stress. CR Acad Sci III-Vie 324:863-868

Kasprzyk I, Myszkowska D, Grewling L, Stach A, Sikoparija B, Skjoth CA, Smith M (2011) The occurrence of Ambrosia pollen in Rzeszów, Kraków and Poznań, Poland: investigation of trends and possible transport of Ambrosia pollen from Ukraine. Int J Biometeorol 55:633-644

Klironomos JN (2002) Feedback with soil biota contributes to plant rarity and invasiveness in communities. Nature 417:67-70

Kuiper PJC (1984) Function of plant cell membranes under saline conditions: membrane lipid composition and ATPases. Pages 77-91 in Staples RC, Toenniesses GH, eds. Salinity Tolerance in Plants. New York: Wiley-Interscience

Laube J, Ziegler, Sparks TH, Estrella N, Menzel A (2015) Tolerance of alien plant species to extreme events is comparable to that of their native relatives. Preslia 87:31-53

Leiblein MC, Losch R (2011) Biomass development and $\mathrm{CO}_{2}$ gas exchange of Ambrosia artemisiifolia L. under different soil moisture conditions. Flora 206:511-516

Leskovšek R, Datta A, Knezevic SZ, Simoncic A (2012b) Common ragweed (Ambrosia artemisiifolia) dry matter allocation and partitioning under different nitrogen and density levels. Weed Biol Manag 12:98-108

Leskovšek R, Eler K, Batic F, Simoncic A (2012a) The influence of nitrogen, water and competition on the vegetative and reproductive growth of common ragweed (Ambrosia artemisiifolia L.). Plant Ecol 213:769-781

Liu J, Xia J, Fang Y, Li T, Liu J (2014) Effects of salt-drought stress on growth and physiobiochemical characteristics of Tamarix chinensis seedlings. Sci World J 2014:765840

Makra L, Juhasz M, Beczi R, Borsos E (2005) The history and impacts of airborne Ambrosia (Asteraceae) pollen in Hungary. Grana 44:57-64

McConnaughay KDM, Coleman JS (1999) Biomass allocation in plants: ontogeny or optimality? A test along three resource gradients. Ecol 80:2581-2593

Moles AT, Flores-Moreno H, Bonser SP, Warton DI, Helm A, Warman L, Eldridge DJ, Jurado E, Hemmings FA, Reich PB, Cavender-Bares J, Seabloom EW, Mayfield MM, Sheil D, Djietror JC, Peri PL, Enrico L, Cabido MR, Setterfield SA, Lehmann CE, Thomson FJ (2012) Invasions: the trail behind, the path ahead, and a test of a disturbing idea. J Ecol 100:116-127

126 • Weed Science 65, January-February 2017 
Ngom R, Gosselin P (2014) Development of a remote sensingbased method to map likelihood of common ragweed (Ambrosia artemisiifolia) presence in urban areas. IEEE J Sel Topics Appl Earth Observ 7:126-139

Onen H, Gunal H, Ozcan S (2014) The Black Sea highway: the route of common ragweed (Ambrosia artemisiifolia L.) invasion in Turkey. Page 76 in Proceedings of the 8th International Conference on Biological Invasions: From Understanding to Action. Antalya,Turkey: XMAT

Onen H, Ozaslan C, Akyol N (2015) Ambrosia artemisiifolia L. in Onen H, ed. Invasive Plants Catalogue of Turkey [in Turkish]. Ankara, Turkey

Ozaslan C, Onen H, Farooq S, Gunal H, Akyol N (2016) Common ragweed: an emerging threat for sunflower production and human health in Turkey. Weed Biol Manag 1:42-55

Petitpierre B, Kueffer C, Broennimann O, Randin C, Daehler C, Guisan A (2012) Climatic niche shifts are rare among terrestrial plant invaders. Science 335:1344-1348

Poorter H, Remkes C, Lambers H (1990) Carbon and nitrogen economy of 24 wild species differing in relative growth rate. Plant Physiol 94:621-627

Pysek P, Chytry M, Pergl J, Sadlo J, Wild J (2012) Plant invasions in the Czech Republic: current state, introduction dynamics, invasive species and invaded habitats. Preslia 84:575-630

Pysek P, Richardson DM (2007) Traits associated with invasiveness in alien plants: where do we stand? Pages 97-125 in Nentwig W, ed, Biological Invasions. Berlin: Springer-Verlag

Rewald B, Shelef O, Ephrath JE, Rachmilevitch S (2013) Adaptive plasticity of salt-stressed root systems. Pages 169-202 in Ahmad P, Azooz MM, Prasad MNV, eds. Ecophysiology and responses of plants under salt stress. New York: Springer

Rothfels CJ, Bearon LL, Dudley SA (2002) The effects of salt, manganese, and density of life history traits in Hesperis matronalis L. from old field and roadside populations. Can J Bot 80:131-139

Sangakkara UR, Frehner M, Nösberger J (2001) Influence of soil moisture and fertilizer potassium on the vegetative growth of mungbean (Vigna radiate L. Wilczek) and cowpea (Vigna unguiculata L. Walp). J Agron Crop Sci 186:73-81

Sarangi D, Irmak S, Lindquist JL, Knezevic SZ, Jhala AJ (2016) Effect of water stress on the growth and fecundity of common waterhemp (Amaranthus rudis). Weed Sci 64:42-52

Simberloff D (2009) The role of propagule pressure in biological invasions. Annu Rev Ecol Evol Syst 40:81-102

Skalova H, Moravcova L, Dixon AFG, Kindlmann P, Pysek P (2015) Effect of temperature and nutrients on the growth and development of seedlings of an invasive plant. AoB Plants 7:plv044

Soberon J (2007) Grinnellian and Eltonian niches and geographic distributions of species. Ecol Lett 10:1115-1123

Steadman KJ, Ellery AJ, Chapman R, Moore A, Turner NC (2004) Maturation temperature and rainfall influence seed dormancy characteristics of annual ryegrass (Lolium rigidum). Aust J Agric Res 55:1047-1057

Storkey J, Stratonovitch P, Chapman DS, Vidotto F, Semenov MA (2014) A process-based approach to predicting the effect of climate change on the distribution of an invasive allergenic plant in Europe. PLoS ONE 9:e88156

Svenning JC, Fløjgaard C, Marske KA, Nógues-Bravo D, Normand S (2011) Applications of species distribution modeling to paleobiology. Quat Sci Rev 30:2930-2947

Ünlükara A, Kurunç A, Kesmez GD, Yurtseven E (2008) Growth and evapotranspiration of okra (Abelmoschus esculentus L.) as influenced by salinity of irrigation water. J Irrig Drain Eng 134:160-166

Vila M, Espinar JL, Hejda M, Hulme PE, Jarosik V, Maron JL, Pergl J, Schaffner U, Sun Y, Pysek P (2011) Ecological impacts of invasive alien plants: a meta-analysis of their effects on species, communities and ecosystems. Ecol Lett 14:702-708

Webster TM, Grey TL (2008) Growth and reproduction of Benghal dayflower (Commelina benghalensis) in response to drought stress. Weed Sci 56:561-566

Wiens JJ, Ackerly DD, Allen AP, Anacker BL, Buckley LB, Cornell HV, Damschen EI, Davies TJ, Grytnes JA, Harrison SP, Hawkins BA, Holt RD, McCain CM, Stephens PR (2010) Niche conservatism as an emerging principle in ecology and conservation biology. Ecol Lett 13:1310-1324

Willemsen RW (1975) Effect of stratification temperature and germination temperature on germination and the induction of secondary dormancy in common ragweed seeds. Am J Bot $62: 1-5$

Xie ZY, Zhang WH, Liu XC (2010) Growth and physiological characteristics of Xanthoceras sorbifolia seedlings under soil drought stress. Acta Bot Boreal-Occident Sin 30:948-954

Yang Sh. H, Ji J, Wang G (2006) Effects of salt stress on plants and the mechanism of salt tolerance. World ScienceTechnology Research \& Development 28:70-76

Zemmer F, Karaca F, Ozkaragoz F (2012) Ragweed pollen observed in Turkey: detection of sources using back trajectory models. Sci Total Environ 430:101-108

Zhu JK, Liu J, Xiong L (1998) Genetic analysis of salt tolerance in Arabidopsis: evidence for a critical role of potassium nutrition. Plant Cell Online 10:1181-1192

Ziska LH, Blumenthal DM, Runion GB, Hunt ER, Diaz- Soltero $\mathrm{H}$ (2011) Invasive species and climate change: an agronomic perspective. Clim Chang 105:13-42

Received January 23, 2016, and approved August 17, 2016.

Associate Editor for this paper: Bhagirath Chauhan, The University of Queensland. 